ISSN 1392-3196 / e-ISSN 2335-8947

Zemdirbyste-Agriculture, vol. 102, No. 2 (2015), p. 229-238

DOI 10.13080/z-a.2015.102.030

\title{
The relationship between wheat baking properties, specific high molecular weight glutenin components and characteristics of varieties
}

\author{
Lina VAICIULYTE-FUNK ${ }^{1}$, Grazina JUODEIKIENE ${ }^{2}$, Elena BARTKIENE ${ }^{3}$ \\ ${ }^{1}$ Food Institute, Kaunas University of Technology \\ Taikos 92, Kaunas, Lithuania \\ ${ }^{2}$ Kaunas University of Technology \\ Radvilènų 19, Kaunas, Lithuania \\ ${ }^{3}$ Lithuanian University of Health Sciences \\ Tilžès 18, Kaunas, Lithuania \\ E-mail: elena.bartkiene@lva.lt
}

\begin{abstract}
The main objective of this study was to compare the aeration level of ring shaped breads, produced from flour made from different winter wheat varieties with different glutenins composition. Analysis of the qualitative and quantitative composition of low molecular weight glutenins (LMW-glutenins), high molecular weight glutenins (HMW-glutenins) and wheat gluten protein fractions $\alpha-, \gamma-\omega$-gliadins was performed by electrophoresis in polyacrylamide gel using sodium dodecyl sulphate polyacrylamide gel electrophoresis (SDS-PAGE). For qualitative evaluation of HMW-glutenin subunits, the obtained electrophoregrams were compared with the standard electrophoretic spectrums of the glutenin components presented in the catalogue. In particular, the indirect acoustic echolocation method can be applied in measurements of the structures of ring shaped breads. Correlations between wheat gluten fractions and some quality parameters characterizing the raw grain material show that HMW-glutenins have the strongest influence on the wheat flour baking properties, and the acoustic method allowed us to assess the quality of ring shaped breads according to the amount of water absorbed and the nature of swelling. This made it possible to classify the ring shaped breads into three quality categories: good (the amount of water absorbed from 37.5 to 50.75 relative units), medium (the amount of water absorbed from 2.54 to 6.28 and from 23.45 to 24.91 relative units), and poor (the amount of water absorbed from 3.6 to 14.7 relative units). According to the specific HMW-glutenin components, it is possible to select the best quality wheat varieties for flour production which could be recommended for ring shaped breads production.
\end{abstract}

Key words: acoustic, glutenins composition, shaped breads, texture parameters, wheat.

\section{Introduction}

By the interaction of wheat flour with water during the mixing of dough intended for ring shaped bread making, the gluten forms a visco-elastic network capable of trapping and retaining gas bubbles (Campbell, Martin, 2012). In modern accelerated-time processes, the bubbles incorporated during mixing have an effect on the texture of the bread/biscuit-like product known as ring shaped bread in East Europe (Saeleaw, Schleining, 2011). The unique properties of a gluten network, which contributes to the elasticity and extensibility of dough, result from the unusual biochemical properties of the gluten proteins. Gluten proteins consist of monomeric gliadins and polymeric glutenins. Gliadins and the glutenins differ in molecular weight, structure and physical properties (Costa et al., 2013). Glutenin like gliadin is quite hydrophobic but it has a very different molecular structure. The baking properties of flour therefore depend on the quality and quantity of gluten (Sciarini et al., 2010). The high molecular weight-glutenin subunits (HMW-GS) play an important role in determining the functional properties of wheat dough. Previous investigations showed that the quality of many bakery products depends on their level of aeration, which could be evaluated by measurement of the total amount of water absorbed and the water absorption dynamics by using an acoustic echolocation method (Juodeikiene et al., 2006). The type of mechanical dough aeration and gas retaining ability of the dough during processing and subsequent proofing and baking stages have been investigated by Peighambardoust et al. (2010), and it was shown that rotational speed in the system influences the aeration and gas holding ability of the dough during proofing and the baking processes. It is 
explained by the fact that higher shear rates could break up the gluten network which had a negative influence on the gas retaining ability. Examination of the relationship between protein fractions of wheat gluten and the quality of ring shaped breads by the acoustic echolocation method has been helpful in the determination of the changes that occur in the physical structures by using different qualities of flour. The structure of baked products, like ring shaped breads, depends to a large extent on the decisive characteristics of dough which is revealed as in rheological and structural properties (Wieser, 2007). Dough density is considered to indicate the changes in the amount of gas entrapped into the dough mechanical development (Romano et al., 2013). Dynamic dough density measurements can distinguish the effects of various dough formulations and processing factors on the production and retention of carbon dioxide gas during proofing (Verheyen et al., 2014). In cereal processing, the company "Brabender" (Germany) has offered a methodology using a farinograph for the evaluation of flour baking properties by valuating a parameter by a quality number as well as a mixing behaviour of dough by different parameters: development time, stability and degree of softening (López, 2014). Among these parameters the quality number is the best to characterize the wheat baking properties. According to the dough stability parameter it is possible to forecast the dough development time by evaluating different specifics of certain wheat baked goods. Growing values of the quality number parameters are stipulated by decreasing values of dough softening. Reviewed scientific studies by Бегеулов (1997) have identified a strong inverse correlation between the quality number and the degree $(r=-0.78 \div-0.92)$ of dough softening. Thus, dough mixing characteristics allow for impartial evaluation of wheat flour baking properties and can forecast the quality of baked goods (Barak et al., 2013 a).

To our knowledge, there are no published data how the traditional farinograph method is related to the dough aeration and gas holding ability in baked goods not to mention in ring shaped breads. Furthermore, it is not known how different gluten structures from different winter wheat genotypes could retain enough air bubbles by ring shaped breads processing. These products are produced from dough with a low moisture content and are subject to quite long fermentation processes and have therefore a specific texture.

Therefore, the main objectives of this study were to analyse gluten composition of different wheat varieties, to evaluate the influence of flour made from different wheat cultivars on aeration level of ring shaped breads, and to apply new indirect acoustic echolocation method for the measurement of structure of ring shaped breads.

\section{Materials and methods}

Wheat samples. Spring ('Munk') and winter ('Portal', 'Širvinta 1', 'Marabu', 'Kosack' and 'Zentos') wheat was harvested in 2010 at the Plant Variety Testing Stations (PVTS) in the Kaunas, Pasvalys and Plunge districts, Lithuania. The research was conducted in 2010-2012 at Kaunas University of Technology.

Protein, sodiumdodecylsulphatepolyacrylamide gel electrophoresis (SDS-PAGE) and electrophoresis comparison analysis. Analysis of the qualitative and quantitative composition of low molecular weight (LMW), high molecular weight (HMW)-glutenins and wheat gluten protein fractions $\alpha-, \gamma$-, $\omega$-gliadins was performed using SDS-PAGE and the composition of the HMW-glutenin fraction which has been previously described by Lesage et al. (2012). Electrophoresis was performed in the lower separating and upper concentrating polyacrylamide gels, gels thickness $1.5 \mathrm{~mm}$ (Payne et al., 1980; Galova et al., 1998) by an apparatus Multigel-Long (Sigma, Germany). For qualitative evaluation of HMWglutenin subunits, the obtained electrophoregrams were compared with the standard electrophoretic spectrums of the glutenin components presented in the catalogue.

Analysis of quantitative composition of wheat gluten protein fractions by SDS-PAGE. The analysis of $\alpha-, \gamma-, \omega$-gliadins and low molecular weight (LMW) and high molecular weight (HMW)-glutenins was carried out by SDS-PAGE. For the analysis of the quantitative composition of proteins, $10 \mathrm{mg}$ of the milled (Laboratory Mill 3100, Perten Instruments, Sweden) sample were treated with $1 \mathrm{~mL}$ of $10 \%$ SDS solution and heated for $30 \mathrm{~min}$ in a boiling water bath. The solution was centrifuged, the obtained supernatant was diluted in mass 3:1 ratio with buffer solution, and heated again for 3-4 min. For electrophoresis, 12\% separating and 4\% concentrated gels were used in a Protean TM II apparatus (Bio-Rad Laboratories Inc., USA).

The composition of the HMW-glutenin fraction was additionally investigated by electrophoresis according to the method of Payne (Payne et al., 1980; Payne, 1986). For the analysis, an $8 \mathrm{mg}$ sample was obtained by grinding a single grain in a porcelain mortar, and put into a $1-1.5 \mathrm{ml}$ centrifuge tube. Buffer solution $(0.2 \mathrm{ml})$ was added and extracted with a solution prepared by mixing $10 \mathrm{ml}$ of buffer solution, $4.2 \mathrm{ml}$ of distilled water and $0.75 \mathrm{ml}$ of 2-mercaptoetanol was extracted for $2 \mathrm{~h}$ at room temperature. The extract was boiled for $2 \mathrm{~min}$ and centrifuged. The sample prepared in this way was used for protein fractioning. Electrophoresis was performed in the lower separating and upper concentrating polyacrylamid gels (thickness $1.5 \mathrm{~mm}$ ) (Galova et al., 1998) by an apparatus MultigelLong (The leading edge in electrophoresis. Protein; Sigma, Germany). For qualitative evaluation of HMWglutenin subunits, the obtained electrophoregrams were compared with the standard electrophoretic spectrums of glutenin components presented in the catalogue (Payne, Lawrence, 1983).

High molecular weight (HMW)-glutenins quality evaluation. Composition of HMW-glutenins was evaluated by using Payne et al. (1980) catalogue. According to the catalogue, gene loci of the HMWglutenins are denoted Glu-A1, Glu-1B and Glu-1D. Proteins subunits are denoted: $0,1,2 *, 2+12,5+10$, $6+7,7+9$ and 22 . The combination of proteins subunit may be rated in points (from 4 to 10 ). For example, 
Glu-1D $(5+10)$ and $G l u-1 D(2+12)$ by relevance for grain production (baking quality) are rated in 7 and 6 quality points.

Quality traits. In the course of the experiment, wheat flour quality parameters were determined. Crude protein content was determined according to ICC 105/2 method (1994). The organic matter of the sample was oxidized with concentrated sulphuric acid in the presence of a catalyst: the product of the reaction $\left(\mathrm{NH}_{4}\right)_{2} \mathrm{SO}_{4}$ was treated by alkali; free ammonia was distilled and titrated. Crude protein is a conventional was expressed for the total content of nitrogenous compounds of the analysed product, calculated by multiplying the corresponding total nitrogen content by an conventional factor. Gluten content and quality was identified according to ICC 155 method (1994). Gluten separated from whole wheat meal or wheat flour by the Glutomatic equipment was centrifuged to force wet gluten through a specially constructed sieve under standardized conditions. The total weight of the gluten was defined as gluten quantity. The percentage of wet gluten remaining on the sieve after centrifugation was defined as the gluten index. If the gluten is very weak all of the gluten may pass through the sieve, the gluten index is 0 . When nothing passes through the sieve, the index is 100 . Wet gluten in wheat flour is a visco-elastic substance made of gliadin and glutenin, which is obtained by means of the specified method contained in this international standard. The gluten index was a measure of the gluten characteristics, which indicates whether the gluten is weak, normal or strong. Sedimentation value was analyzed according to ICC 116/1 method (1994). Swelling of the gluten fraction of flour in lactic acid solution affects the rate of sedimentation of a flour suspension in the lactic acid medium. Higher gluten content and better gluten quality both give rise to slower sedimentation and higher sedimentation test values. The degree of sedimentation of a flour suspended in a lactic acid solution during a standard time interval is taken as a measure of baking quality. Starch content was analyzed according to ICC 123/1 method (1994). The soluble, optically active compound accompanying the substance under examination were extracted with $10 \%$ ethanol and removed by filtration or centrifugation. The starch remaining in the residue was dissolved in hot, dilute hydrochloric acid, dissolved proteinanceous substances were precipitated with Carrez solution (I and II) and filtered. The optical rotation of the starch solution in the filtrate was measured and from this the starch content is calculated. Rheological properties of wheat flour dough (water absorption, dough development time, stability, degree of softening, quality number, valorimeter value) was analysed by the farinograph "Brabender" (Brabender OHG, Germany) (ISO 5530-1:1997).

Ring shaped breads making and quality evaluation. Experimental baking of ring shaped breads was carried out under normal production conditions at the company "Javinè" (Lithuania). The recipe for the production of vanilla flavoured ring shaped breads was: $100 \mathrm{~kg}$ wheat flour, $37 \mathrm{~kg}$ water, $10 \mathrm{~kg}$ sugar, $5 \mathrm{~kg}$ fat, 2 $\mathrm{kg}$ pressed yeast and $1 \mathrm{~kg}$ salt. The dough was prepared by a single-phase method by mixing all the ingredients in a periodic mixing machine T2M63 (Russia) for 15-20 min. The dough was divided into $5-7 \mathrm{~kg}$ portions, rolled in a machine H4M2330 (Russia) and fermented at $26^{\circ} \mathrm{C}$ for $1.5 \mathrm{~h}$. This operation was performed on a conveyor belt, where the dough sheet was covered by a linen cloth. The dough was shaped in a machine B-4-58PS (Russia) and the half-finished product was left to rise on a conveyor rising machine for $2 \mathrm{~h}$ (at $35^{\circ} \mathrm{C}$ and $70 \%$ relative humidity), followed by treatment with a water-steam mixture at $110^{\circ} \mathrm{C}$ for $4.5 \mathrm{~min}$. The products were baked in an oven PXC-25M (Russia) at $220^{\circ} \mathrm{C}$ for $14 \mathrm{~min}$.

Acoustic measurements. The quality of ring shaped breads was evaluated by the acoustic echolocation method, in which the speed of water absorption (nature of swelling) of the roll in time is followed by measuring the changes in water level during the measurement (the swelling dynamics) (Juodeikiene et al., 2006). Arbitrary ranges of amounts of water in relative units (RU) were chosen as to classify the quality of the ring shaped breads as good, medium and poor. The main scheme of the experimental equipment for the investigation of absorbed liquid volume of porous products is shown in Figure 1.

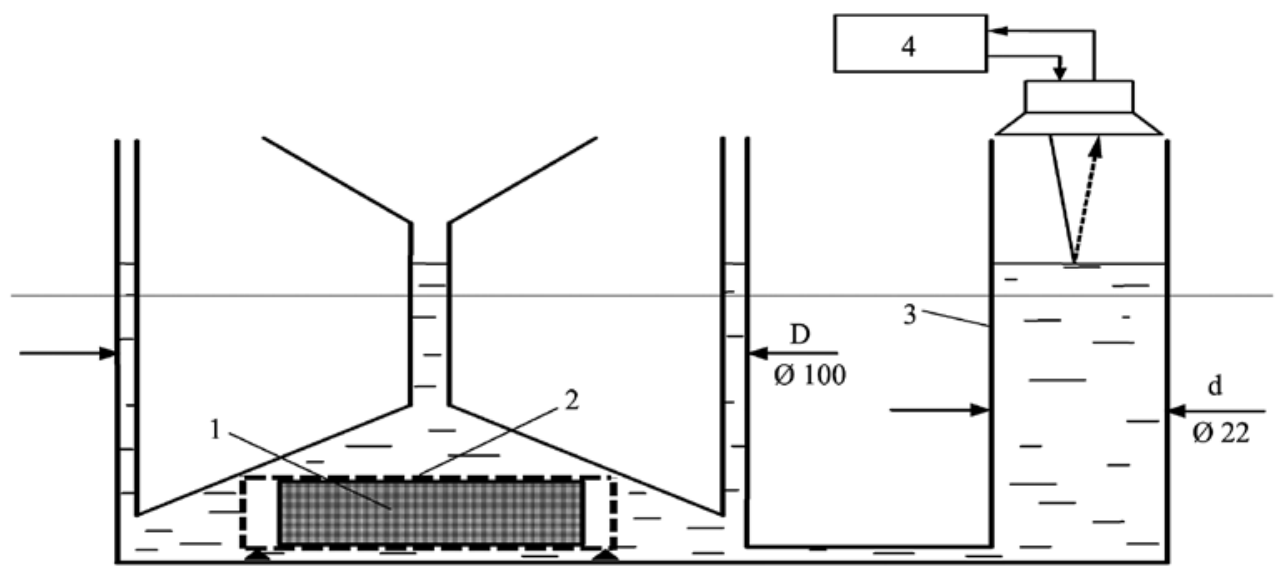

Note. 1 - the sample under investigation, 2 - the reticular case for the sample, 3 - the liquid measurement part, 4 - the acoustic liquid level meter; $\mathrm{D}$ and $\mathrm{d}$ are the diameters of the respective liquid measurement parts.

Figure 1. The block diagram of the experimental equipment for the investigation of absorbed liquid volume of porous products 
Statistical analysis. The data were analyzed using statistical software package SPSS, version 11.0 (SPSS Inc., USA). The general analysis of variance was performed.

\section{Results and discussion}

Characteristics of wheat flour quality. The results of the studied wheat flour quality parameters are presented in Table 1. The protein content in the different flours ranged from $9.4 \%$ to $14.2 \%$ (Table 1 ). The highest protein content was determined in the flour made from the winter wheat varieties 'Portal' (14.2\%), 'Zentos' $(12.8 \%)$, 'Śirvinta 1' $(11.2 \%)$ and the spring wheat variety 'Munk' (12.0\%), grown in Kaunas. The values of wet gluten amount and the gluten index in the analyzed samples changed from $13.8 \%$ to $32.8 \%$ and from 11.0 to 94.0 RU. The highest gluten amount is a characteristic of the flour produced from 'Munk' $(26.83 \%)$, 'Portal' (32.8\%) and 'Zentos' (29.2\%), grown in Kaunas, while the optimal gluten index (GI) is a characteristic of the flour produced from 'Portal' (Pasvalys, GI - 75 RU) and 'Munk' (Plungé, GI - 83 RU).

Table 1. Quality parameters of different wheat flour

\begin{tabular}{cccccccc}
\hline $\begin{array}{c}\text { Flour } \\
\text { from }\end{array}$ & Location & $\begin{array}{c}\text { Moisture } \\
\%\end{array}$ & $\begin{array}{c}\text { Sedimentation } \\
\text { index } \\
\mathrm{ml}\end{array}$ & $\begin{array}{c}\text { Starch } \\
\%\end{array}$ & $\begin{array}{c}\text { Protein } \\
\% \text { DM }\end{array}$ & $\begin{array}{c}\text { Gluten } \\
\%\end{array}$ & $\begin{array}{c}\text { Gluten index } \\
\text { RU }\end{array}$ \\
\hline \multirow{2}{*}{ 'Munk' } & Kaunas PVTS & $13.0 \pm 0.25$ & $31 \pm 0.23$ & $73.2 \pm 0.41$ & $12.0 \pm 0.46$ & $26.83 \pm 0.82$ & $46 \pm 0.82$ \\
& Plungė PVTS & $11.3 \pm 0.89$ & $29 \pm 0.56$ & $67.7 \pm 0.59$ & $11.6 \pm 0.14$ & $23.21 \pm 0.76$ & $83 \pm 0.23$ \\
\hline \multirow{2}{*}{ 'Sirvinta 1' } & Kaunas PVTS & $12.4 \pm 0.47$ & $24 \pm 0.81$ & $75.1 \pm 0.32$ & $11.2 \pm 0.38$ & $24.72 \pm 0.15$ & $24 \pm 0.92$ \\
& Pasvalys PVTS & $11.0 \pm 0.08$ & $25 \pm 0.65$ & $71.7 \pm 0.72$ & $10.4 \pm 0.29$ & $25.05 \pm 0.48$ & $25 \pm 0.37$ \\
& Plunge PVTS & $11.3 \pm 0.47$ & $21 \pm 0.19$ & $70.4 \pm 0.23$ & $10.7 \pm 0.05$ & $26.01 \pm 1.13$ & $21 \pm 0.42$ \\
\hline \multirow{2}{*}{ 'Portal' } & Kaunas PVTS & $12.7 \pm 0.45$ & $41 \pm 0.24$ & $71.7 \pm 0.56$ & $14.2 \pm 0.27$ & $32.79 \pm 0.52$ & $20 \pm 0.54$ \\
& Pasvalys PVTS & $11.2 \pm 0.28$ & $36 \pm 0.36$ & $76.6 \pm 0.63$ & $10.5 \pm 0.81$ & $21.45 \pm 0.64$ & $75 \pm 0.58$ \\
& Plunge PVTS & $11.7 \pm 0.67$ & $34 \pm 0.16$ & $72.5 \pm 0.18$ & $12.1 \pm 0.13$ & $31.42 \pm 0.76$ & $28 \pm 0.31$ \\
\hline \multirow{2}{*}{ 'Zentos' } & Kaunas PVTS & $12.4 \pm 0.28$ & $48 \pm 0.72$ & $68.7 \pm 0.72$ & $12.8 \pm 0.81$ & $29.23 \pm 0.62$ & $41 \pm 0.59$ \\
& Pasvalys PVTS & $11.3 \pm 0.32$ & $49 \pm 0.31$ & $75.5 \pm 0.38$ & $11.8 \pm 0.19$ & $17.14 \pm 0.24$ & $94 \pm 0.27$ \\
\hline \multirow{2}{*}{ 'Kosack' } & Kaunas PVTS & $12.8 \pm 0.08$ & $19 \pm 0.56$ & $75.4 \pm 0.05$ & $10.3 \pm 0.34$ & $23.5 \pm 0.18$ & $22 \pm 0.49$ \\
& Pasvalys PVTS & $11.0 \pm 0.17$ & $16 \pm 0.13$ & $75.0 \pm 0.29$ & $9.4 \pm 0.43$ & $20.94 \pm 0.26$ & $20 \pm 0.29$ \\
& Plunge PVTS & $13.1 \pm 0.97$ & $19 \pm 0.43$ & $76.3 \pm 0.67$ & $10.6 \pm 0.63$ & $25.15 \pm 0.16$ & $24 \pm 0.79$ \\
\hline \multirow{2}{*}{ 'Marabu' } & Kaunas PVTS & $12.4 \pm 1.03$ & $13 \pm 0.4$ & $73.5 \pm 0.12$ & $12.1 \pm 0.62$ & $16.94 \pm 0.82$ & $13 \pm 1.02$ \\
& Pasvalys PVTS & $11.0 \pm 0.48$ & $10 \pm 0.16$ & $78.9 \pm 0.58$ & $9.5 \pm 0.34$ & $12.23 \pm 0.47$ & $10 \pm 0.27$ \\
& Plunge PVTS & $12.1 \pm 0.59$ & $11 \pm 0.61$ & $75.7 \pm 0.42$ & $10.5 \pm 0.31$ & $13.78 \pm 0.69$ & $11 \pm 0.58$ \\
\hline
\end{tabular}

DM - dry matter, RU - relative units; PVTS - Plant Variety Testing Station

Analysis of the wheat chemical composition shows that the protein content seems to be the most important feature of differentiating genotypes. The quality of gluten (insoluble proteins) depends on the proportion of protein fractions in grains (Hasniza et al., 2014). The quality of gluten depends on the size of glutenin molecules that had formed during grain maturation and this has an impact on the wheat baking properties (Barak et al., 2013 b). Because the insoluble proteins seem to be mainly involved in the process of dough formation (Sivam et al., 2010), the next stage of the work was concentrated on the analysis of the wheat gluten composition.

Table 2. Gliadin and glutenin fractions of the wheat flour
Variation in the storage proteins. Analysis of the electrophoretic spectrums of insoluble protein fractions of wheat (varieties 'Munk', 'Širvinta 1', 'Portal', 'Zentos', 'Kosack' and 'Marabu') identified the following gliadin and glutenin fractions: $\alpha$-gliadins (31$32 \mathrm{kD}$ (kilodaltons)), $\gamma$-gliadins (38-42 kD), $\omega$-gliadin (44-64 and 70-74 kD) subunits, LMW-glutenins (36-38 and 42-44 kD) and HMW-glutenins (64-70 and 95-136 $\mathrm{kD}$ ) subunits (Table 2).

The investigation showed that the relative amounts of sulphur-poor $\Omega$-gliadins and HMW-glutenins varied in the analyzed samples from $32.91 \%$ to $47.92 \%$

\begin{tabular}{|c|c|c|c|c|c|c|c|c|c|c|c|c|c|c|c|}
\hline \multirow{4}{*}{$\begin{array}{l}\text { Flour } \\
\text { from }\end{array}$} & \multicolumn{15}{|c|}{ Relative amount of gluten protein fractions $\%$} \\
\hline & \multicolumn{9}{|c|}{ sulphur-rich } & \multicolumn{6}{|c|}{ sulphur-poor } \\
\hline & \multicolumn{3}{|c|}{$\alpha$-gliadins } & \multicolumn{3}{|c|}{$\gamma$-gliadins } & \multicolumn{3}{|c|}{ LMW-glutenins } & \multicolumn{3}{|c|}{$\omega$-gliadins } & \multicolumn{3}{|c|}{ HMW-glutenins } \\
\hline & $\mathrm{I}$ & II & III & I & II & III & I & II & III & I & II & III & $\mathrm{I}$ & II & III \\
\hline 'Munk' & 3.43 & - & 3.74 & 12.11 & - & 13.4 & 25.03 & - & 7.09 & 32.91 & - & 47.15 & 6.93 & - & 3.33 \\
\hline 'Širvinta 1' & 2.41 & 2.32 & 2.42 & 15.21 & 15.47 & 8.01 & 23.43 & 18.34 & 28.3 & 39.32 & 42.82 & 40.36 & 8.43 & 8.31 & 7.51 \\
\hline 'Portal' & 4.11 & 3.48 & 2.51 & 15.15 & 12.1 & 13.13 & 12.53 & 9.4 & 21.55 & 43.21 & 47.92 & 42.31 & 2.73 & 5.91 & 6.9 \\
\hline 'Zentos' & 3.2 & 3.11 & - & 16.17 & 17.33 & - & 11.82 & 7.33 & - & 44.3 & 46.22 & - & 1.77 & 1.81 & - \\
\hline 'Kosack' & 2.91 & 3.24 & 3.92 & 21.4 & 21.88 & 21.47 & 6.61 & 9.37 & 10.91 & 43.24 & 40.71 & 41.51 & 3.21 & 5.48 & 5.43 \\
\hline 'Marabu' & 2.21 & 2.35 & 2.9 & 10.31 & 5.55 & 10.31 & 24.93 & 32.01 & 22.08 & 41.64 & 40.1 & 40.26 & 11.05 & 10.32 & 11.4 \\
\hline
\end{tabular}

LMW - low molecular weight, HMW - high molecular weight; I - Kaunas, II - Pasvalys, III - Plungė Plant Variety Testing Stations (PVTS) 
and from $1.77 \%$ to $11.4 \%$, respectively. $\Omega$-gliadins predominated among the gluten fractions and differed in amount depending on the genotypes (Table 2). The greatest amount of this fraction was found in 'Zentos' $(44.3 \div 46.22 \%)$ and in 'Portal' $(42.31 \div 47.92 \%)$, the lowest - in 'Munk' $(32.91 \div 47.15 \%)$. The amount of other gluten fraction of low sulphur content - HMW-glutenins - can vary in the analyzed wheat depending on both the genotype ('Zentos' and 'Širvinta 1') and the growing conditions ('Munk', 'Marabu', 'Portal' and 'Kosack'). The greatest amount of this fraction was found in 'Marabu' $(10.32 \div 11.4 \%)$ and 'Śirvinta 1 ' $(7.51 \div 8.43 \%)$, the lowest - in 'Zentos' $(1.77 \div 1.81 \%)$. The amount of sulphur-rich fractions - A-, $\Gamma$-gliadins and LMW-glutenins - varied in the analyzed samples between $2.21-4.11 \%, 5.55-21.88 \%$ and $6.61-32.01 \%$, respectively.

Quantitative differences among some of these protein fractions ( $\gamma$-gliadins and HMW-glutenins) in the different wheat varieties are strongly influenced by the growing conditions (Table 2). The highest amount of $\gamma$-gliadins is specific to 'Kosack' (21.4-21.88\%) in Kaunas and Pasvalys PVTS, while that of LMWglutenins - to 'Marabu' (32.01\%) in Pasvalys and 'Munk' $(25.03 \%)$ in Kaunas. The lowest amount of $\gamma$-gliadins in these fractions was found in 'Marabu' $(5.55 \%)$ in Pasvalys, while that of LMW-glutenins in 'Kosack' $(6.61 \%)$ in Kaunas. Other parameters such as the amount of a sulphur-rich A-gliadin fraction in the analyzed grain material were determined by the genotype. The highest content of this protein fraction was found in 'Munk' $(3.43 \div 3.74 \%)$, while the lowest content - in 'Marabu' $(2.21 \div 2.9 \%)$ and 'Širvinta 1 ' $(2.32 \div 2.42 \%)$.

High molecular weight (HMW)-glutenin subunit compositions. This part is comprised of an additional investigation on the composition of HMWglutenin fraction of wheat varieties grown in Lithuania (Table 3). 'Širvinta 1' and 'Portal' possess the best baking properties having $8.5-9.5$ quality points. In these wheat varieties $G l u-1 A 1, G l u-1 B(7+8), G l u-1 B(7+9)$ and Glu-1D $(5+10)$ subunits were identified. In the wheat variety 'Širvinta 1', an additional component, Glu-1B22 was also found. This component does not occur in the other wheat varieties. The wheat varieties 'Širvinta 1' and 'Portal' distinguish themselves by good baking properties. Satisfactory baking properties (6-7 points) were found to be characteristic of the wheat varieties 'Zentos', 'Munk' and 'Kosack'.

Table 3. High molecular weight (HMW) glutenin subunit composition of wheat flour

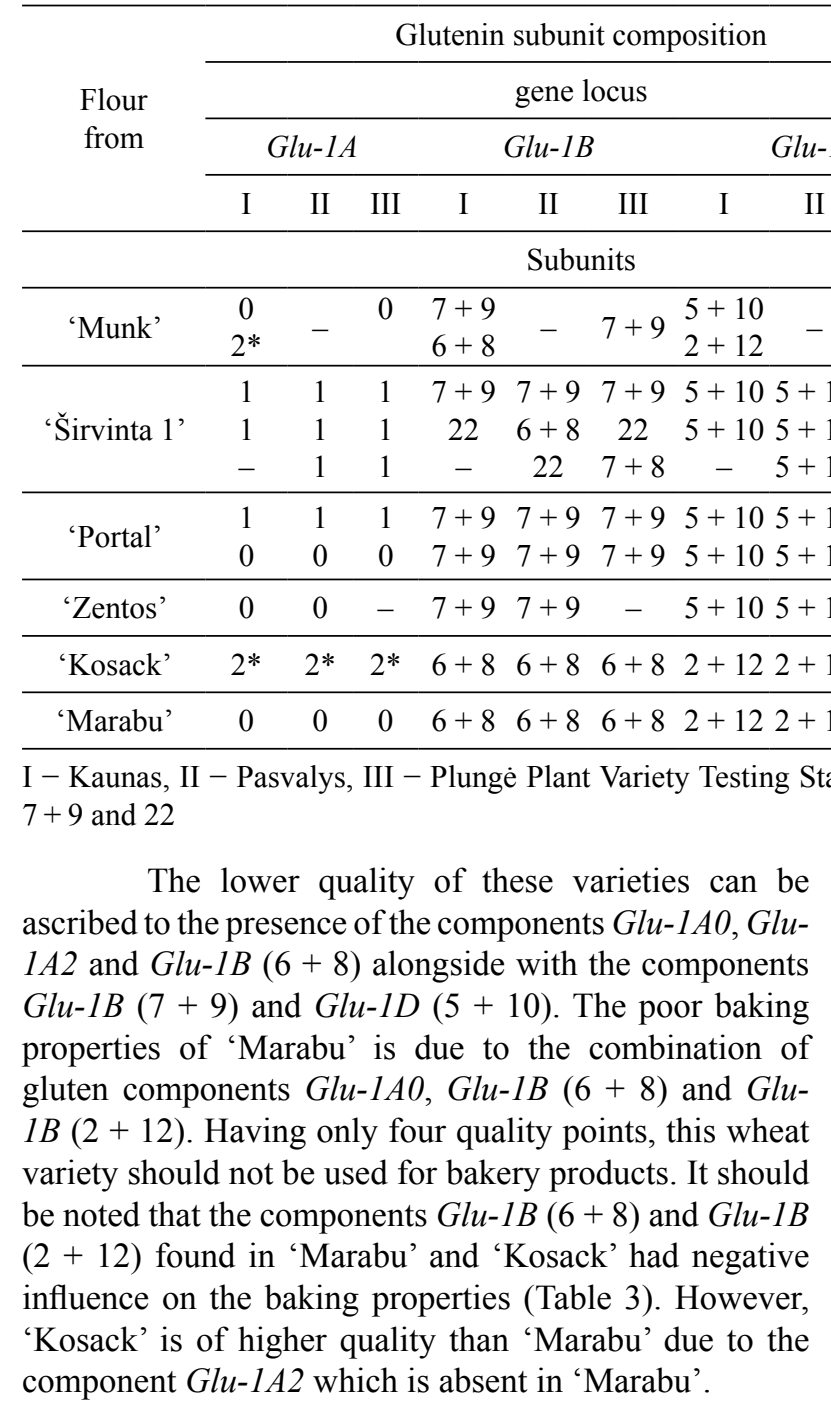



and characteristics of varieties

Table 4. Wheat flour mixing properties investigated by the farinograph

\begin{tabular}{|c|c|c|c|c|c|c|c|c|c|c|c|c|c|c|c|c|c|c|}
\hline \multirow[t]{2}{*}{$\begin{array}{l}\text { Flour } \\
\text { from }\end{array}$} & \multicolumn{3}{|c|}{$\begin{array}{c}\text { Water absorption } \\
\%\end{array}$} & \multicolumn{3}{|c|}{$\begin{array}{c}\text { Dough } \\
\text { development time } \\
\text { min }\end{array}$} & \multicolumn{3}{|c|}{$\begin{array}{l}\text { Stability } \\
\text { min }\end{array}$} & \multicolumn{3}{|c|}{$\begin{array}{c}\text { Degree } \\
\text { of softening } \\
\text { FU }\end{array}$} & \multicolumn{3}{|c|}{$\begin{array}{l}\text { Quality number } \\
\text { mm }\end{array}$} & \multicolumn{3}{|c|}{$\begin{array}{c}\text { Valorimeter value } \\
\text { RU }\end{array}$} \\
\hline & I & II & III & I & II & III & I & 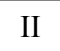 & & $T$ & II & III & I & & & I & & III \\
\hline 'Munk' & 65.4 & - & & 2.8 & - & 2.0 & 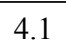 & . & 1.2 & 02 & - & 5 & 00 & - & 155 & & 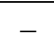 & 59 \\
\hline 'Širvinta 1' & 64.9 & 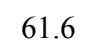 & . & 1.9 & 1.0 & 2.0 & 7.0 & . & 2.0 & 00 & 105 & 98 & (O) & 47 & 38 & 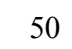 & 50 & 42 \\
\hline 'Ports & 67.9 & 63 & 65. & 3.5 & 1.8 & 2.4 & 3.7 & 8.5 & 3.8 & 30 & 2 & 62 & 145 & 1 & 68 & & & 50 \\
\hline 'Zentos' & 6. & 60.0 & - & 1 & 1 & - & 9.2 & 05 & - & 10 & 1 & - & 130 & 1 & - & 65 & 61 & - \\
\hline 'Kosa & 59.7 & w & 58.6 & 1.8 & 1.4 & 1.8 & 2.4 & 2 & 2.6 & 90 & 80 & 80 & 38 & 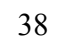 & 48 & 45 & 46 & 42 \\
\hline 'Marabu' & 58.7 & 54.9 & 58.3 & 2.1 & 1.3 & 1.5 & 1.5 & 2.0 & 1.3 & 30 & 62 & 75 & 95 & 37 & 105 & 47 & 40 & 44 \\
\hline
\end{tabular}

FU - farinograph units, RU - relative units; I - Kaunas, II - Pasvalys, III - Plunge Plant Variety Testing Stations (PVTS)

'Portal', 'Širvinta 1' and 'Zentos') are remarkable and influenced by the genotype-specific. The peak of water absorption was identified in the samples of 'Portal' (65.6 $\pm 2.3 \%)$, 'Širvinta 1' $(63.0 \pm 1.7 \%)$, 'Zentos' (61.7 \pm $2.3 \%)$ and 'Munk' $(62.0 \pm 4.9 \%)$, the least values where in the samples of 'Kosack' $(57.7 \pm 2.5 \%)$ and 'Marabu' $(57.3 \pm 2.1 \%)$. Not only the structure of gluten protein but also the bonding within the protein plays important roles in the dough development and functionality. Proteins contain covalent and noncovalent bonds that contribute to dough formation and structure (Hoseney, 1994; Bushuk, 1998). Noncovalent bonds include hydrogen bonding, hydrophobic interactions, ionic bonds and van der Waals interactions (Hoseney, 1994). Although hydrogen bonds are individually weak, they create stability to the dough when large numbers of bonds are established during dough development. Hydrophobic and ionic bonds, although present in very small amounts, play significant roles in the interactions among the biopolymers within bread dough that consequently promote dough stability. It was determined that dough development time was short when 1.6 to 1.9 minutes were recorded for the analyzed samples of 'Kosack', 'Marabu', 'Zentos' and 'Širvinta 1' wheat. Those samples showed a good flour quality, whereas the samples from 'Munk' and 'Portal' wheat were characterised by long dough development time (2.4-2.5 $\mathrm{min})$. Farinograph dough stability time is an important index for classifying wheat, and it often indicates the most appropriate end use for the wheat cultivars (Tian et al., 2007). Investigation results pointed out that moderate values of dough stability, degree of softening and quality number varied in wide intervals $1.6-8.9 \mathrm{~min}, 10.0-87.6 \mathrm{FU}$ and $41.3-127.5 \mathrm{~mm}$, respectively.

Results showed, that not only the genotype but also other growing factors (contamination of wheat with fungal strains) are influencing the properties of flour. The best baking properties were distinguished for wheat varieties 'Zentos' $(63.0 \pm 2.8)$, 'Portal' $(56.3 \pm 7.1)$ and 'Munk' $(56.0 \pm 4.2)$ RU, the worst baking properties were for the wheat varieties 'Kosack' $(44.3 \pm 3.5)$ and 'Marabu' (43.7 \pm 3.5$)$ RU.
Many researchers calculate the valorimeter value, which is determined by the length of time required to mix the flour to minimum mobility and the descending slope. The larger the valorimeter value, the stronger - in terms of breadmaking potential - the flour (Pomeranz, Meloan, 2002). Valorimeter value, derived by means of a special template, is an empirical quality score, and the higher values indicate stronger flour. The valorimeter value of all tested samples exceeds the 40 RU limit which indicates that they all are suitable for the production of wheat baked goods (Keeratipibul et al., 2013).

Absorbed water quantity of the tested ring shaped breads samples from different wheat flour. Results of the absorbed water quantity of tested ring shaped breads made from different wheat flour, and results of HMW-glutenin and HMW-glutenin score are presented in Figure 2. The ring shaped breads made from 'Marabu' wheat variety flour exhibited good structural properties of the crumb and are attributed to the good quality class. During swelling for 15 minutes the samples evenly absorbed 37.5 to 50.75 subunits of water. After swelling, the samples taken out of the water by a strainer were uniformly soft, retained their shape, the structure in the cross section of the crumb was even. These data were confirmed by the results of wheat quality and dough mixing properties (Table 4). A significant HMW-glutenin fraction from $10.32 \%$ to $11.4 \%$ was determined in wheat variety 'Marabu', although the HMW-glutenin quality according to Payne's et al. (1980) methodology was estimated by four points - combination of ingredients Glu-1A0, Glu-1B $(6+8)$ and Glu-1D $(2+12)$ (Table 3). The total protein content in the analyzed samples was 9.5-12.1\%, gluten content $-12.2-16.9 \%$, gluten index - 11-13, sedimentation indicator - 11-13 $\mathrm{ml}$, water absorption was established by the farinograph -54.9 $58.7 \%$.

Medium baking properties (HMW-glutenin determination according to Payne scored 6-7) were typical of varieties 'Zentos', 'Munk' and 'Kosack'. Samples of ring shaped breads baked of these wheat varieties flour are attributed to the medium class. The composition of their glutenin components compared with 


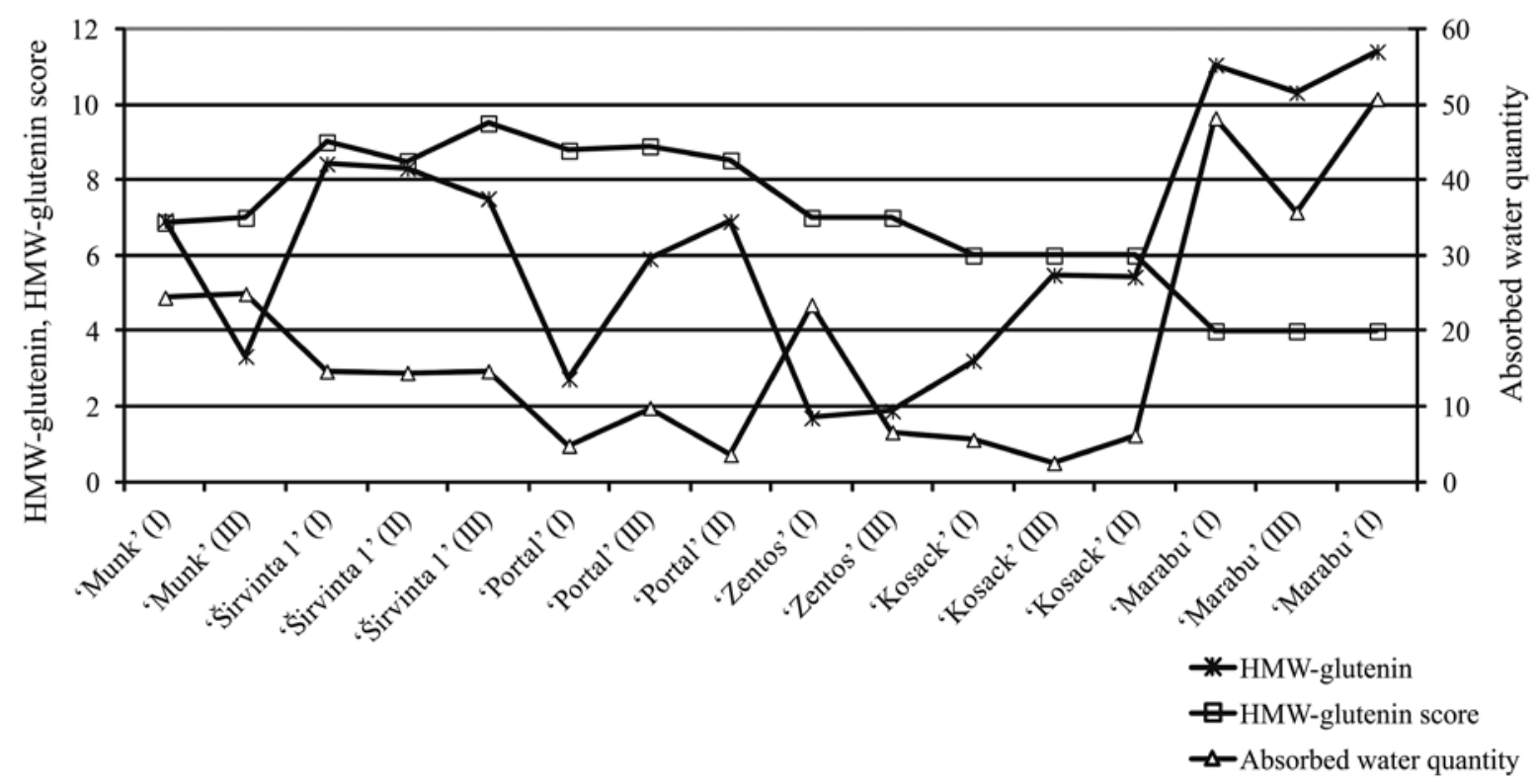

I - Kaunas, II - Pasvalys, III - Plungè Plant Variety Testing Stations (PVTS)

Figure 2. Absorbed water quantity of tested ring shaped breads made from different wheat flour, high molecular weight (HMW)-glutenin, HMW-glutenin score

wheat variety 'Marabu' was more diverse. Additionally, in the compositions Glu-1A0, Glu-1A2, Glu-1B $(7+9)$ and $G l u-1 D(5+10)$ HMW-glutenin components were determined. The ring shaped breads made from wheat varieties 'Zentos' and 'Munk' exhibited average structural properties of the crumb. During swelling for 15 minutes the ring shaped breads evenly absorbed from 23.45 to 24.91 subunits (Fig. 2). After swelling, the samples taken out of the water by a strainer were unevenly soft, only in a partially preserved form; the crumb cross section of the structure was uneven, with an imbalance occurring in the structure and insufficient swollen areas. The ring shaped breads prepared from the wheat variety 'Kosack' flour absorbed small quantities of water during swelling (from 2.54 to 6.28 subunits). Their quality can be evaluated as average due to structure defects. In this case, the samples were swollen unevenly: the outer layers under the crust were sufficiently swollen and the inside part remained un-swollen. The baked products that distinguished themselves as of medium quality (according to the swelling indicators) were prepared from flour with a protein content of $9.4 \%$ to $12.8 \%$, gluten content $-17.1-$ $29.2 \%$, gluten index - 20-94 subunits, sedimentation rate $-16-49 \mathrm{ml}$, water absorption was measured by the farinograph-57.7-62.0\%. Comparing the HMW-glutenin composition of the wheat variety 'Kosack' with HMWglutenin composition of the wheat variety 'Marabu', the Glu-1A2 component was additionally determined.

The ring shaped breads prepared from 'Portal' and 'Širvinta 1' wheat varieties flour absorbed smaller quantities of water (from 3.6 to 14.7 subunits). In these cases, the ring shaped breads after 15 minutes of swelling retained their shape; only the crust and about $2 \mathrm{~mm}$ thick layer of crumb were swollen. The inner structure of the crumb remained solid and un-swollen. Thus, according to the results of the tests, these samples are attributed to the poor quality class.

The quality evaluation of wheat varieties 'Portal' and 'Širvinta 1' according to HMW component composition meets 8.5 to 9.5 points according to Payne methodology (1983). In the studied samples there are 2-3 HMW component, which content in wheat varieties is different. In the wheat variety 'Portal' Glu-1A0, Glu- $1 B$ $(7+9)$ and Glu-1D $(5+10)$ composition of components dominates (76.0-89.2\%), while the composition of components is much lower Glu-1A2, Glu-1B $(7+9)$ and Glu-1D $(5+10)$, the percentage is significantly lower (4.8-24.0\%). A more diverse composition of components was established in the wheat variety 'Širvinta 1'. Here different percentages of HMW content consist from components: Glu-1A1, Glu-1B $(7+9)$, Glu-1D $(5+10)$ -23.3-56.8\%, Glu-1A1, Glu-1B22, Glu-1B $(6+8)$, Glu$1 D(5+10)-8.3-76.7 \%$, Glu-1A1, Glu-1B22, Glu-1B $(7+8)$ and $G l u-1 D(5+10)-4.7-58.4 \%$. The quality indicators and dough mixing characteristics of wheat varieties 'Širvinta 1' and 'Portal' showed good baking characteristics: protein content - 10.4-14.2\%, gluten content $-21.4-32.8 \%$, gluten index $-21-24$ ('Širvinta 1') and 20-75 ('Portal') RU, sedimentation rate - 21-24 ('Širvinta 1') and 34-41 ('Portal') ml, but they were not found to be suitable for good quality ring shaped breads production.

It was found that the most suitable for the ring shaped breads production are flours made from wheat with higher HMW-glutenin content (10.32-11.4\%) and HMW-glutenin specific combination (Glu-1A0, Glu- 
$1 B(6+8)$ and $G l u-1 D(2+12))$, having a low protein content: with a total amount of protein $-9.5-12.1 \%$, gluten content $-12.2-16.9 \%$, gluten index $-11-13$ RU and sedimentation rate $-11-13 \mathrm{ml}$.

The categories of ring shaped breads were: good (amount of water absorbed 37.5-50.75 RU), medium (amount of water absorbed 2.54-6.28 and 23.45-24.91 RU) and poor (amount of water absorbed 3.6-14.7 RU).

According to Peighambardoust et al. (2010), dough with a higher consistency tends physically to entrap more air bubbles upon processing, leading to higher dough volume and, thereby lower density of the end product. The ring shaped rolls produced from dough with higher dough stability demonstrated a better developed structure and based on it a higher water absorption capability. Furthermore, this study showed that hydration plays a major initial role in modifying the protein structure in the dough during mixing. Upon the start of mixing, hydration occurs at the surfaces of flour particles. The interaction of water with flour rapidly builds a connected gluten network locally within the dough during its initial formation, irrespective of the mixing. According to Anderssen (2007), the role of mixing is not only the dough development but also the initial equal distribution of water within the flour. The role of water distribution and hydration in the development of the dough was confirmed by Peighambardoust et al. (2010). The obtained results of sensory evaluation of ring shaped rolls revealed that quality of flour and HMW-glutenin subunits are of crucial importance for the production of the end products with an optimal texture for the consumer.

\section{Conclusions}

1. Gluten protein fractions in the winter wheat (varieties 'Portal', 'Kosack', 'Širvinta 1', 'Marabu', 'Zentos', 'Munk') are: $\alpha$-gliadins $(2.2-4.1 \%), \gamma$-gliadins (5.5-21.4\%), $\omega$-gliadins (32.9-47.9\%), low molecular weight (LMW) (6.6-32.0\%) and high molecular weight (HMW) (1.7-11.4\%) glutenins.

2. In the wheat varieties with moderate baking properties ('Zentos', 'Munk', 'Kosack'), Glu-1A0, Glu$1 A 2$, Glu-1B $(6+8)$, Glu-1B $(7+9)$ and Glu-1D $(5+10)$ predominate. In 'Marabu', a wheat variety of low baking quality, the major components were Glu-1A0, Glu-1B $(6+8)$ and $G l u-1 B(2+12)$.

3. The acoustic method allowed us to assess the quality of ring shaped breads according to the amount of water absorbed and the nature of swelling: good quality - the amount of water absorbed 37.5-50.75 RU (relative units), medium quality - the amount of water absorbed 2.54-6.28 and 23.45-24.91 RU, poor quality - the amount of water absorbed 3.6-14.7 RU.

4. The most suitable for ring shaped breads production is the flour prepared from wheat grain with a higher HMW-glutenin content - 10.32-11.4\%, and their specific composition - Glu-1A0, Glu-1B $(6+8)$ and Glu-
$1 D(2+12)$, and total protein content $9.5-12.1 \%$, gluten content - 12.2-16.9\%, gluten index - 11-13 RU and sedimentation rate $-11-13 \mathrm{ml}$.

Received 23072014

Accepted 23012015

\section{References}

Anderssen R. S. 2007. Wheat-flour dough rheology. Belton P. (ed.). The chemical physics of food. Oxford, UK http://dx.doi.org/10.1002/9780470995792.ch7

Barak S., Mudgil D., Khatkar B. S. 2013 (a). Effect of composition of gluten proteins and dough rheological properties on the cookie-making quality. British Food Journal, 115 (4): 564-574 http://dx.doi.org/10.1108/00070701311317847

Barak S., Mudgil D., Khatkar B. S. 2013 (b). Relationship of gliadin and glutenin proteins with dough rheology, flour pasting and bread making performance of wheat varieties. LWT - Food Science and Technology, 51 (1): 211-217 http://dx.doi.org/10.1016/j.lwt.2012.09.011

Bushuk W. 1998. Interactions in wheats dough. Hammer R. J., Hoseney R. C. (eds.). Interactions: the keys to cereal quality. St Paul, USA, p. 1-16

Campbell G. M., Martin P. J. 2012. Bread aeration and dough rheology: an introduction. Cauvain S. P. (ed.). Breadmaking: improving quality $\left(2^{\text {nd }}\right.$ ed.). Cambridge, UK, p. 299-336 eScholarID:170264

Costa M. S., Scholz M. B. S., Franko C. M. L. 2013. Effect of high and low molecular weight glutenin subunits, and subunits of gliadin on physicochemical parameters of different wheat genotypes. Food Science and Technology, 33 (1): $163-170$ http://dx.doi.org/10.1590/S0101-20612013000500024

Galova L., Smolkova A., Michalik S., Gregova E. 1998. Prediction of bread-making quality of wheat grain on the base of electrophoretic spectrums of HMW glutenin subunits. Rostlinna vyroba, 44: 111-116

Hasniza N. M. Z., Wilkes A. M., Uthayakumaran S., Copeland L. 2014. Growth environment influences grain protein composition and dough functional properties in three Australian wheat cultivars. Cereal Chemistry, 91 (2): 169-175 http://dx.doi.org/10.1094/CCHEM-05-13-0109-R

Hoseney R. C. 1994. Proteins of cereals. Principles of cereal science and technology. St Paul, USA, p. 65-101

ICC 105/2. 1994. Determination of crude protein in cereals and cereal products for food and for feed

ICC 116/1 1994. Determination of the sedimentation value (according to Zeleny) as an approximate measure of baking quality

ICC 123/1 1994. Determination of starch content by calcium chloride dissolution

ICC 155. 1994. Determination of wheat gluten quantity and quality (gluten index according to Perten) of whole wheat meal and wheat flour (Triticum aestivum)

ISO 5530-1. 1997. Wheat flour - Physical characteristics of doughs. Part 1. Determination of water absorption and rheological properties using a farinograph 
Juodeikiene G., Petrauskas A., Jakubauskiene L., Minialga V. 2006. Development of an indirect method for evaluating porous cereal product structures using acoustic echolocation. Measurement Science and Technology, 17: $249-256$ http://dx.doi.org/10.1088/0957-0233/17/2/004

Kaddour A., Barron C., Robert P., Cuq B. 2008. Physicochemical description of bread dough mixing using twodimensional near-infrared correlation spectroscopy and moving-window two-dimensional correlation spectroscopy. Journal of Cereal Science, 48: 10-19 http://dx.doi.org/10.1016/j.jcs.2007.07.008

Keeratipibul S., Luangsakul N., Otsuka S., Sakai S., Hatano Y., Tanasupawat S. 2013. Effects of the amount of Chinese steamed bun starter dough (CSB-SD) and activation time on dough and bread properties. Journal of Food Processing and Preservation, 37 (3): 232-244 http://dx.doi.org/10.1111/j.1745-4549.2011.00640.x

Lesage V. S., Rhazi L., Aussenac T., Meleard B., Branlard G. 2012. Effects of HMW- \& LMW-glutenins and grain hardness on size of gluten polymers. Proceedings of $11^{\text {th }}$ International Gluten Workshop. Beijing, China, p. $200-205$

López E. P. 2014. Influence of the addition of lupine protein isolate on the protein and technological characteristics of dough and fresh bread with added Brea Gum. Food Science and Technology, 34 (1): 195-203

http://dx.doi.org/10.1590/S0101-20612014005000016

Payne P. I. 1986. Varietal improvement in the bread-making quality of wheat: contributions from biochemistry and genetic and future prospects from molecular biology. Biotechnology and Crop Improvement and Protection, 34: 69-81

Payne P. I., Lawrence G. J. 1983. Catalogue of alleles for the complex gene loci, Glu-A1, Glu-B1, and Glu-D1 which code for high molecular weight subunits of glutenin in hexaploid wheat. Cereal Research Communications, 11 (1): 29-35

Payne P. I., Harris P. I., Law C. N., Holt L. M., Blackman L. A. 1980. The high-molecular-weight subunits of glutenin: structure, genetics and relationship of bread-making quality. Annales de Technologie Agricole, 29 (2): 309-320 Record Number 19821608251

Peighambardoust S. H., Fallan E., Hamer R. J., van der Good M. 2010. Aeration of bread dough influenced by different way of processing. Journal of Cereal Science, 51: 89-95 http://dx.doi.org/10.1016/j.jcs.2009.10.002

Pomeranz Y., Meloan C. E. 2002. Food analysis: theory and practice, p. $28-778$

Romano A., Cavella S., Toraldo G., Masi P. 2013. 2D structural imaging study of bubble evolution during leavening. Food Research International, 50 (1): 324-329 http://dx.doi.org/10.1016/j.foodres.2012.10.040

Saeleaw M., Schleining G. 2011. A review: crispness in dry foods and quality measurements based on acousticmechanical destructive techniques. Journal of Food Engineering, 105 (3): 387-399 http://dx.doi.org/10.1016/j.jfoodeng.2011.03.012

Sciarini L. S., Ribotta P. D., León A. E., Pérez G. T. 2010. Influence of gluten-free flours and their mixtures on batter properties and bread quality. Food and Bioprocess Technology, 3 (4): 577-585 http://dx.doi.org/10.1007/s11947-008-0098-2
Sivam S. A., Sun-Waterhouse D., Quek S. Y., Perera C. O. 2010. Properties of bread dough with added fiber polysaccharides and phenolic antioxidants: a review. Journal of Food Science, 75 (8): R163-R174 http://dx.doi.org/10.1111/j.1750-3841.2010.01815.x

Tian J., Hu R., Deng Z., Wang Y., 2007. The variation and stability analysis of wheat dough stability time. Agricultural Sciences in China, 6 (2): 143-149 http://dx.doi.org/10.1016/S1671-2927(07)60028-5

Verheyen C., Jekle M., Becker T. 2014. Effects of Saccharomyces cerevisiae on the structural kinetics of wheat dough during fermentation. LWT-Food Science and Technology, 58 (1): 194-202 http://dx.doi.org/10.1016/j.1wt.2014.02.050

Wesley I. J., Larsen N., Osborne B. G., Skerritt J. H. 1998. Non-invasive monitoring of dough mixing by near infrared spectroscopy. Journal of Cereal Science, 27 (1): 61-69 http://dx.doi.org/10.1006/jcrs.1997.0151

Wieser H. 2007. Chemistry of gluten proteins. Food Microbiology, 24 (2): 115-119 http://dx.doi.org/10.1016/j.fm.2006.07.004

Бегеулов М. Ш. 1997. Оценка качества пшеницы на фаринографе. Хлебопродукты, 12: 11-12 (in Russian) 
ISSN 1392-3196 / e-ISSN 2335-8947

Zemdirbyste-Agriculture, vol. 102, No. 2 (2015), p. 229-238

DOI 10.13080/z-a.2015.102.030

\title{
Kviečių kepamųjų savybių priklausomumas nuo specifinių didelès molekulinės masès gliuteninų komponentų, o jų sandaros - nuo kviečių veislès savybių
}

\author{
L. Vaičiulytė-Funk ${ }^{1}$, G. Juodeikienè ${ }^{2}$, E. Bartkienè $\dot{e}^{3}$
}

${ }^{1}$ Kauno technologijos universiteto Maisto institutas

${ }^{2}$ Kauno technologijos universitetas

${ }^{3}$ Lietuvos sveikatos mokslų universitetas

\section{Santrauka}

Tyrimo tikslas - ịvertinti ịvairių veislių kviečių gliuteninų sudèti ir palyginti riestainių, pagamintų iš žieminių kviečių, pasižyminčių skirtinga gliuteninų sudètimi, aeracijos laipsnį, taikant nekontaktinį akustinį metodą. Nustatyta esminė koreliacija tarp tirtų kviečių glitimo frakcijų ir miltų vandens absorbcijos. Galima teigti, kad didelès molekulinès masès gliuteninai turi įtakos kviečių kepimo savybėms, o nekontaktinis akustinis metodas gali būti taikomas iš šių kviečių miltų pagamintų riestainių kokybei ịvertinti pagal absorbuoto vandens kiekị ir brinkimo pobūdį. Pagal šias savybes riestainių kokybę sąlygiškai galima suskirstyti ị tris kategorijas: geros kokybès (absorbuoto vandens kiekis nuo 37,5 iki 50,75 sąlyginių vienetų), vidutinès kokybès (absorbuoto vandens kiekis nuo 2,54 iki 6,28 ir nuo 23,45 iki 24,91 sąlyginių vienetų) ir prastos kokybès (absorbuoto vandens kiekis nuo 3,6 iki 14,7 sąlyginių vienetų). Remiantis tyrimo duomenimis galima teigti, kad kviečių kepimo savybès priklauso nuo specifinių didelès molekulinès masės gliuteninų komponentų, o jų sandara - nuo kviečių veislès genetinių savybių.

Reikšminiai žodžiai: akustika, gliuteninų kompozicija, kviečiai, riestainiai. 